\title{
Excavations at the Seila Pyramid and Ritual Ramifications
}

Kerry Muhlestein

Brigham Young University - Provo, kerry_muhlestein@byu.edu

Follow this and additional works at: https://scholarsarchive.byu.edu/facpub

Part of the Ancient, Medieval, Renaissance and Baroque Art and Architecture Commons

\section{Original Publication Citation}

"Excavations at the Seila Pyramid and Ritual Ramifications," in Excavations at Fag el-Gamous and the Seila Pyramid, Kerry Muhlestein, editor in chief, Krystal V. L. Pierce and Bethany Jensen, eds., Harvard Egyptological Studies vol. 7. (Leiden: Brill, 2019), 48-75.

\section{BYU ScholarsArchive Citation}

Muhlestein, Kerry, "Excavations at the Seila Pyramid and Ritual Ramifications" (2019). Faculty Publications. 3563.

https://scholarsarchive.byu.edu/facpub/3563

This Book Chapter is brought to you for free and open access by BYU ScholarsArchive. It has been accepted for inclusion in Faculty Publications by an authorized administrator of BYU ScholarsArchive. For more information, please contact ellen_amatangelo@byu.edu. 
Excavations at the Seila Pyramid and Ritual Ramifications

Kerry Muhlestein

This is the author's submitted version of a chapter that was published as "Excavations at the Seila Pyramid and Ritual Ramifications," in Excavations at Fag el-Gamous and the Seila Pyramid, Kerry Muhlestein, editor in chief, Krystal V. L. Pierce and Bethany Jensen, eds., Harvard Egyptological Studies vol. 7. (Leiden: Brill, 2019), 48-75.

[page 48]

\section{History of Excavation of the Pyramid}

In modern times it was not apparent that the structure many travelers had seen atop the remote escarpment in Gebel El-Rus was actually a pyramid. ${ }^{1}$ Before its excavation it was locally known as el-Qalah, meaning "the fortress," 2 though it has since come to be called Harem Seila, or the Seila Pyramid. Even before excavation it could be easily seen as far away as Hawara when the air was clear. ${ }^{3}$ Though it stood six miles straight west of the Meidum Pyramid, there was nothing about the visible square covered in aeolian sand that would make explorers or archaeologists think it was another Snefru pyramid. Even the first real archaeologists to survey the area did not realize what it was. Petrie briefly explored there, but his cursory examination did not uncover enough to dissuade him from what met his initial glance: that he was looking at a mastaba. ${ }^{4}$ Petrie estimated the height to be about 25 feet, which is less than a third of what it originally was. He also thought it was most likely a $12^{\text {th }}$ dynasty tomb. A layer on the west side had been removed at some point, though Petrie could not tell this at the time. Its removal made the pyramid seem more rectangular than it really was, causing it to look more like a mastaba. He wisely wrote that it would take more exploration to tell what was really going on with the monument. ${ }^{5}$

\footnotetext{
${ }^{1}$ On the geologic makeup of the area, see Russel D. Hamblin, "The Geology of the Gebel El-Rus Area and Archaeology Sites in the Eastern Fayum, Egypt," in Excavations at Seila, Egypt, C. Wilfred Griggs, ed. (Provo, UT: Religious Studies Center, Brigham Young University, 1988), 45-73.

${ }^{2}$ Nabil Swelim, "The BYU Expedition to Seila, in the Fayum, Egypt: The Pyramid of Seila Locally Called 'el Qalah:' The Season of 1987" accessed May 2019, http://nabilswelim.com/downloads/Seila n let.pdf.pdf.

${ }^{3}$ See W. M. F. Petrie, Illahun, Kahun and Gurob 1889-90, (London: D. Nutt, 1891), 31.

${ }^{4}$ Ibid., and plate XXX.

5 Ibid.
} 
[page 49]

There must have been some reports that the structure was a pyramid, for when Grenfell and Hunt excavated in the nearby cemeteries, they wrote that they were "south of the 'pyramid' of Sêla, an Old Empire mastaba." ${ }^{6}$ While they averred that the structure was a mastaba, their quotations around the word makes it clear that some regarded it as a "pyramid."

Later, Borchardt performed more serious, though still brief, work. It was he who published that the structure was indeed a pyramid, calling it a step pyramid. ${ }^{7} \mathrm{He}$ mentioned that the antiquities service guards called it a pyramid. ${ }^{8}$ That, combined with Grenfell's and Hunt's use of the term, suggests that the locals had known all along that it was a pyramid, and that it took some time for foreigners to accept the idea.

While working there, Borchardt reports having recovered a double statue of a man and a woman and a painted statue of a man, both recovered from what he called unauthorized excavations. ${ }^{9}$ The painted statue of a man who is wearing a kilt and is striding with his hands clenched and hanging to his side, is about $55.5 \mathrm{~cm}$ tall. The statue of an official who is striding with his arms at his side next to a woman (presumably his wife), who is standing and has one arm around him while the other is at her side, is about $70.5 \mathrm{~cm}$ tall. Because they seem to have been produced from local illicit digging, it is difficult to tell where exactly they were found. To be clear, Borchardt does not state that the statues were from the pyramid, but rather just lists "Sile," as the provenance. Thus it is possible that the statues were uncovered at the village of Seila. Still, since Borchardt did not concentrate his work there but rather at the pyramid, the village seems an unlikely provenance. While Borchardt reports that he did not find any kind of cemetery in that area, ${ }^{10}$ Grenfell and Hunt did, indicating that there surely was one in the area. ${ }^{11}$ An Old Kingdom necropolis seems a likely site for such statues. Thus it appears that either the pyramid, but

\footnotetext{
${ }^{6}$ Bernard P. Grenfell and Arthur S. Hunt, "Graeco-Roman Branch: Excavations in the Fayum and at El Hibeh," in Archaeological Report:1901-1902, F. Ll. Griffith, ed. (London: Egypt Exploration Fund, 1902), 2.

${ }^{7}$ Ludwig Borchardt, "Die Pyramide von Silah: Auszug aus einem Berichte," Annales du Service des Antiquites de l'Egypte 1 (1900): 211-214.

${ }^{8}$ Borchardt, "Die Pyramide von Silah," 211.

${ }^{9}$ Ludwig Borchardt, Statuen und Statuetten von Königen und Privatleuten im Museum von Kairo, Nr. 1-1294, Teil 1 (Berlin: Reichsdruckerei, 1911), 6-7 and plate 2. Figures 5 and 6 are the single and double statues respectively.

${ }^{10}$ Borchardt, "Die Pyramide von Silah," 214.

${ }^{11}$ See the article on the background of the Fayoum in this volume.
} 
perhaps even [page 50] more likely, the necropolis of Seila are the possible potential origins of these statues. ${ }^{12}$

Borchardt performed limited exploration at the pyramid, only measuring some of its most exposed layers. He estimated that the base was 30 long strides, ${ }^{13}$ an observation that would prove to be close to accurate (assuming that a stride was about a meter). Borchardt noted that he thought it was an Old Kingdom structure. ${ }^{14} \mathrm{He}$ also noted its orientation, building material, and some construction elements, all of which lead him to believe it to be one of the largest of the minor step pyramids, ${ }^{15}$ an idea which many still hold today. ${ }^{16}$ The ritual elements present at the pyramid are an important part as to why the current [page 51] excavator does not support this opinion. ${ }^{17}$ This conclusion is further augmented by the presence of angled casing stones and a

\footnotetext{
${ }^{12}$ Andrzej Ćwiek, "Date and Function of the So-Called Minor Step Pyramids," Göttinger Miszellen 162 (1998): 43 fn 24, stated that these statues came from a cemetery rather than the pyramid. For this he cited Grenfell and Hunt's report of work in 1900-1901. See Bernard P. Grenfell and Arthur S. Hunt, "Graeco-Roman Branch: Excavations in the Fayum," in Archaeological Report: 1900-1901, ed. F. Ll. Griffith (London: Egypt Exploration Fund, 1901), 47. However, the cemetery he spoke of was reported in Bernard P. Grenfell and Arthur S. Hunt, "Graeco-Roman Branch: Excavations in the Fayum and at El Hibeh," in Archaeological Report: 1901-1902, F. Ll. Griffith, ed. (London: Egypt Exploration Fund, 1902), 2-5. While Grenfell and Hunt speak of finding a cemetery there which they felt came from the Old Kingdom, they do not speak of any finds in the report, nor anywhere else we have searched in their records. They do not record anything about finding these two statues. In another publication, see Andrzej Ćwiek, "Fayum in the Old Kingdom," Göttinger Miszellen 160 (1997): 21. Ćwiek says that the statues "may come" from the necropolis. Therefore we conclude it is best to rely on Borchardt's publication saying these were from Seila, possibly, though not certainly, from the pyramid.

${ }^{13}$ Borchardt, "Die Pyramide von Silah," 212.

${ }^{14}$ Ibid., 213.

${ }^{15}$ Ibid., 212-213.

${ }^{16}$ See, for example, Rainer Stadelmann, "Snofro - Builder and Unique Creator of Pyramids of Seila and Meidum," in Echoes of Eternity: Studies Presented to Gaballa Aly Gaballa, Ola El-Aguizy and Mohamed Sherif Ali, eds. (Wiesbaden: Harrassowitz Verlag, 2010), 35. Here Stadelmann speaks of Seila as one of the most curious of the small step pyramids. He also felt it was built even before the Meidum pyramid. See also Alexander Badawy, $A$ History of Egyptian Architecture, Vol. I, From the Earliest Times to the End of the Old Kingdom (Cairo: Studio Misr, 1954), 125; and Jan Bock, "Die kleinen Stufenpyramiden des frühen Alten Reiches. Ein Überblick," Sokar 7 , no. 12 (2006): 21-22. The most recent publication, Franck Monnier, "The satellite pyramid of Meidum and the problem of the pyramids attributed to Snefru," The Journal of Ancient Egyptian Architecture 3 (2018): 14, refers to it as a "provincial" pyramid, but compares its structure to the Meidum pyramid. It should also be noted that the pyramid was at times proposed to be the burial place of Huni or Hetepheres. Ćwiek, "Date and Function of the SoCalled Minor Step Pyramids," 47-48 (though he does not hold to this theory); and Jean-Philippe Lauer, Histoire monumentale des pyramides d'Égypte, tome 1 (Cairo: Institut Français d'Archéologie Orientale, 1962), 230. This theory has been disregarded both because there is no apparent burial chamber and because of the Snefru stela found on site.

${ }^{17}$ This opinion was reached independently by the author, but was also held by Nabil Swelim and Gunther Dreyer. See Ćwiek, "Date and Function of the So-Called Minor Step Pyramids," 42. Ćwiek was of the opinion that the Seila Pyramid held more in common with the minor step pyramids than it had as a difference, but also felt that the Seila Pyramid was the key to understanding the others.
} 
knowledge of its original size, which was extensively larger than has been commonly reported. ${ }^{18}$ Apparent connections with the Meidum Pyramid are further reason. ${ }^{19}$ These last two ideas will be explored more fully in future publications.

Borchardt published a few photographs of the pyramid that help document its state over the years. ${ }^{20} \mathrm{He}$ also reports having found a worked ("bearbeitetet") basalt block. ${ }^{21}$ Swelim, who excavated later, also reports finding three fragments of basalt, but does not record where. ${ }^{22}$ Two small basalt fragments were discovered in the 2018 season on the eastern side near the causeway. The northern desert of the Fayoum contains a basalt quarrying site, at Widan el-Faras. This is the likely source for whatever basalt was used at the pyramid. Because limestone casing for the pyramid has been found, it seems most likely that the "worked" basalt belonged to the cultic structures on either the north or east side. Since Borchardt says he saw the stone while ascending to the pyramid, and because one ascends to the pyramid on the north side, this seems the most likely place Borchardt would have seen the basalt. Thus it seems likely that the northern cultic porch had some basalt in it, a feature that would be employed by Snefru's son in the cultic structures around his pyramid. At the same time the presence of a few basalt fragments on the eastern side suggests that the cultic area there may also have been paved in basalt.

The next time the pyramid was investigated was in 1938 when Pochan cursorily explored the monument. He did not add very much new information, but [page 52] he did take five timely and important photographs that help preserve a knowledge of its state at the time. ${ }^{23}$ Lauer drew a reconstruction in the early 1960's after a short survey. ${ }^{24}$ Again, because it had not yet been more fully excavated, the reconstruction was somewhat faulty, but his measurements were much more

\footnotetext{
${ }^{18}$ As was presented by Kerry Muhlestein and Brent Benson in a lecture titled "(Re)Constructing Snefru's Pyramids: Insights Gained from Precise GPS Measurements," (presentation, ARCE Annual Meeting, Cincinnati, OH, April 2013).

${ }^{19}$ Ibid., and a lecture by Kerry Muhlestein titled "Discovering and Understanding Parallel Programs at Snefru's Pyramids," (presentation, Society for the Study of Egyptian Antiquities Annual Scholars Colloquium, Toronto, ON, November 2009); and a lecture by C. Wilfred Griggs and Kerry Muhlestein, titled "The Seila Pyramid, Ritual Considerations and Parallels," (presentation, ARCE Annual Meeting, Berkeley, CA, April 2010). Some of these connections were already anticipated by Jean Yoyotte, "Études géographiques II: Les localités méridionales de la région memphite et 'le Pehou d'Héracléopolis," Revue d'Égyptologie 14 (1962): 98.

${ }^{20}$ Borchardt, "Die Pyramide von Silah," figures 1, 3, and 4.

${ }^{21}$ Ibid., 213-214.

${ }^{22}$ Nabil Swelim, "The BYU Expedition to Seila," 6.

${ }^{23}$ Andre Pochan, Pyramide de Seila (au Fayoum), BIFAO 37 (1938) : 161, plates 1-2.

${ }^{24}$ Laure, Histoire monumentale des pyramides d'Égypte, Fig 61 and plate LXIX; also Lauer, "Les petites pyramides à degrés de la IIle dynastie," RA 2 (1961): 5-15.
} 
accurate and it was he who first recognized that there may have been an outer facing. Lauer also postulated that the pyramid was a $3^{\text {rd }}$ or $4^{\text {th }}$ Dynasty tomb for a king or queen. ${ }^{25}$

Kaiser and Dreyer briefly surveyed the pyramid as part of their exploration of minor step pyramids. ${ }^{26}$ In this exploration they theorized that, while it was in many ways similar to the minor step pyramids, it was also unique because of its larger size and distance from the Nile. ${ }^{27}$ They also posited that it was a $3^{\text {rd }}$ or $4^{\text {th }}$ Dynasty structure. Gunter and Dreyer provided accurate measurements of what had been excavated at that point, noted the use of headers and stretchers, and determined that the mortar was a mixture of sand and clay. ${ }^{28}$ Still, the full extent of the pyramid had not yet been uncovered.

\section{The Lesko Excavation}

In January 1981, the first sustained and systematic excavation was undertaken by a joint University of California, Berkeley-Brigham Young University (BYU) team. ${ }^{29}$ In that year, headed by Leonard Lesko who was assisted by C. Wilfred Griggs, an initial clearing of sand and two soundages were accomplished. The work of beginning to clear the sand was substantial. Wind is almost always present at the crest of the escarpment. The loose sand from the desert is carried up, and as the wind encounters the end of the hill it drops the sand it had carried with it. This happens continually, but each spring a khamseen brings strong enough winds to move large amounts of sand up to the summit where it is left on top of the pyramid. Thus the large structure had become almost [page 53] completely buried over time. Clearing the loose sand from about half of the pyramid and excavating to uncover the corners revealed that the pyramid was larger than had been thought. The visible bottom of the pyramid in the center of the western wall, the part that had been cleared before, was not really the bottom of the pyramid. The hill had not been completely leveled, but rather part of it had been incorporated into the pyramid structure. The corners of the pyramid were significantly lower than the bottom of the middle of the western

\footnotetext{
${ }^{25}$ Lauer, “Les petites pyramides, ” 10, 15; Lauer, Historie monumentale, 224.

${ }^{26}$ Gunter Dreyer and Werner Kaiser, "Zu den kleinen Stufen pyramiden Ober-und Mittelägyptens," MDAIK 36 (1980): 42. Archaeological Institute of America," American Journal of Archaeology 86/2 (1982): 275; and Leonard Lesko, "Seila 1981," JARCE 25 (1988): 223-35.
} 
wall. ${ }^{30}$ Thus the pyramid was substantially taller than had been once thought. Additionally, considerable amounts of the outer wall on the south and east sides had been plundered, making it appear smaller than it originally had been, though enough stonework remained, especially of the headers, that the size of the walls could be determined. ${ }^{31}$ The blocks of the pyramid measured, on average, $1 \times 0.5 \times 0.5$ meters. $^{32}$

Lesko found a small ancient coin inside the debris of the east wall. While it was illegible, Lesko felt it recognizable enough to theorize that the wall had been at least partially cleared in late antiquity, and that perhaps some of the stone blocks present in the nearby late antique cemetery had come from the pyramid. ${ }^{33}$ Looking for subsidiary structures, Lesko cleared small spaces around the east, south and west sides, finding nothing. He also conducted a seismometer test in these areas around the pyramid during this season. He found no anomalies, suggesting that there are no underground cavities, though the geological material there is not ideal for conducting seismic waves. ${ }^{34}$

No consequential objects were found that year. Further, nothing that helped determine who the builder was had been uncovered. Thus the excavators speculated that the structure was either $3^{\text {rd }}$ or $5^{\text {th }}$ Dynasty. ${ }^{35}$ While this theory was incorrect, a few very important things were accomplished that season. Enough of the surface was cleared to find what was assumed to be the corners of the building, allowing for a better estimation of its size to be made, though that would be modified over time. Removing sand from the top layer made [page 54] something Petrie had found even more apparent. The pyramid had been plundered from the north side, right into its core.

Presumably someone had assumed the existence of a northern entrance to what could have been a chamber, and the plundering was in search of such a feature.

\footnotetext{
${ }^{30}$ Leonard Lesko, "Seila 1981," 226.

${ }^{31}$ Ibid.

${ }^{32}$ C. Wilfred Griggs, "Excavating a Christian Cemetery Near Seila, in the Fayum Region of Egypt," in Coptic Studies, Acts of the Third International Congress of Coptic Studies, ed. Wlodzimierza Godlewskiego (Warsaw: Panstwowe Wydawnictwo Naukowe, 1990), 145.

${ }^{33}$ Lesko, "Seila 1981," 226.

${ }^{34}$ See Nabil Swelim, "An Aerial View of the Layer Monument of Snfrw at Seila," in Zeichen aus dem Sand. Streiflichter aus Ägyptens Geschichte zu Ehren von Günter Dreyer, Menes - Studien zur Kultur und Sprache der ägyptischen Frühzeit und des Alten Reiches, Eva-Maria Engel, Vera Müller, and Ulrich Hartung, eds. (Wiesbaden, Germany: Harrassowitz, 2008), 5:652.

${ }^{35}$ Lesko, "Excavation Report: Seila in the Fayoum, 1981," 275.
} 


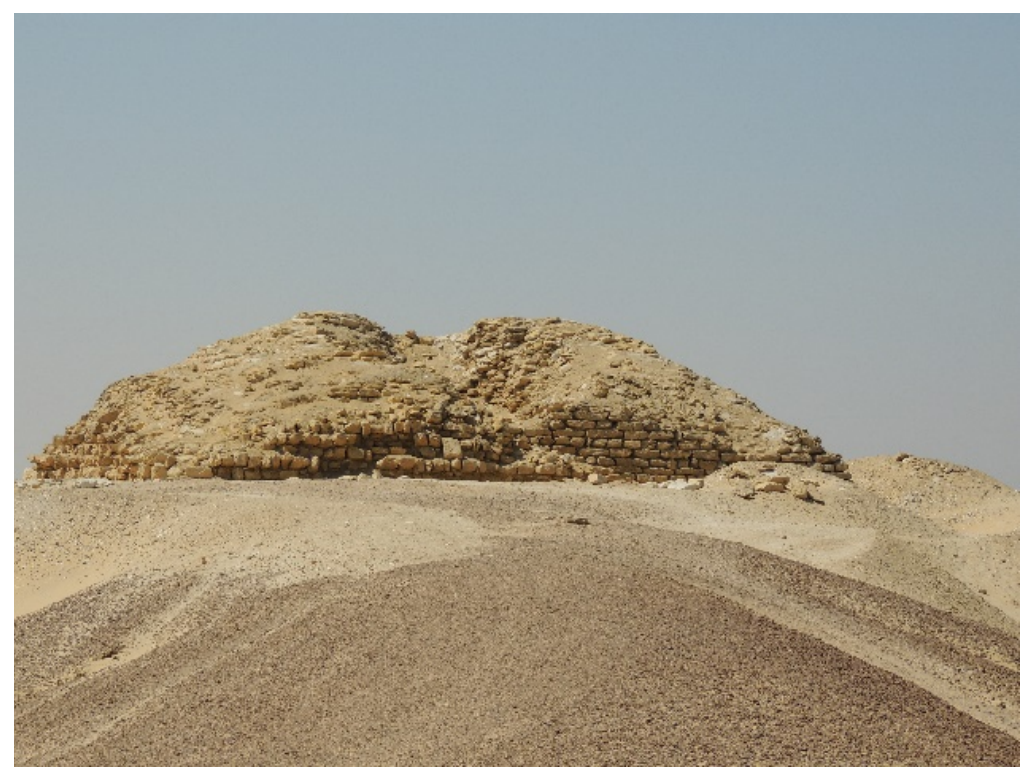

Figure 3.1: Northern side of the pyramid with the "looting trench" visible. Photo by Kerry Muhlestein

We cannot tell when, during the 4600 year life of the pyramid, this plundering occurred. In later excavation of some of the rubble left by these plunderers, a tobacco label was uncovered ${ }^{36}$ which suggests that the plundering might have taken place when one of its early $19^{\text {th }}$ or $20^{\text {th }}$ century excavators had been at work. Yet Petrie noted the trench cutting into its north side when he did the first modern published exploration. ${ }^{37} \mathrm{He}$ did not investigate enough to see that the plundering was as extensive as it was, so it is possible that a trench had begun before his day, while the disassembly of so much of the pyramid was done by later excavators. There has even been speculation that Mariette or Maspero could have dug such a trench before Petrie got there, ${ }^{38}$ though we have no record of their having worked at Seila. Petrie thought that the trench looked recent (like at Dashur and Kula) and was cleared down to three feet [page 55] below the pavement level. ${ }^{39}$ Borchardt thought that the trench was probably dug in antiquity, but might also be more modern. ${ }^{40}$ It is also possible that later archaeologists examined the pile of debris as well, and that this was when the cigar wrapper became part of those remains. Most likely the full plundering of the pyramid happened before Petrie's day, probably long before, though we will never be sure.

\footnotetext{
${ }^{36}$ Ibid.; and Swelim, “An Aerial View,” 652.

${ }^{37}$ Petrie, Illahun, Kahun and Gurob 1889-90, 31.

${ }^{38}$ Nabil Swelim, "The BYU Expedition to Seila."

${ }^{39}$ Petrie, Illahun, Kahun and Gurob 1889-90, 31.

${ }^{40}$ Borchardt, "Die Pyramide von Silah," 212-13.
} 
The plundering makes it impossible to tell if there was a chamber in the pyramid. Yet it is most plausible that there was not, since it seems likely a plunderer or excavator would stop when they encountered a chamber, leaving at least its floor intact. At present there is no trace of anything suggesting the remains of a chamber has been uncovered.

\section{The 1987 Season}

After the first season in 1981 Lesko moved from UC Berkeley to Brown University, and the Egypt Antiquities Organization asked BYU to continue the project, headed by Griggs. Part of the concession included a large necropolis known as Fag el-Gamous, which had also received survey attention in the inaugural season. Because modern agriculture was threatening to encroach upon the cemetery site, Griggs determined that the cemetery would take priority and that work on the Seila Pyramid would have to wait several years.

Work on the pyramid began again in February $1987 .{ }^{41}$ At this point, Griggs assumed that the pyramid was a $3^{\text {rd }}$ Dynasty Step Pyramid. ${ }^{42}$ As a result of this assumption, Nabil Swelim, who had been working on minor step pyramids for some time, was invited to direct the work at the pyramid. He was assisted by two foremen who regularly worked for the German Archaeological Institute, Aly Awaad and his assistant, El Tayeb Hassan. This work was at the behest of, and was overseen by, Griggs, who personally headed the work that continued at the cemetery below. Revell Phillips, a professor of geology from BYU, and George Homsey, a professional architect and a founding partner of the architectural firm, Esherik, Homsey, Dodge, and Davis, based in San Francisco, also [page 56] assisted with the work. While many of the details of the excavation work were either not recorded or have been lost, we are fortunate that Swelim published a few articles in Festchrifts ${ }^{43}$ as well as self-publishing a number of descriptions, pictures, and drawings of the excavation of the Seila Pyramid. Without his careful work during and after excavation, we would know far less about this monument.

\footnotetext{
${ }^{41}$ Swelim, "The BYU Expedition to Seila," 1-6; Swelim, “An Aerial View," 647-653; Swelim, "Reconstructions of the Layer Monument of Snfrw at Seila," 39-56.

${ }^{42}$ C. Wilfred Griggs, "Excavating a Christian Cemetery Near Seila, in the Fayoum Region of Egypt," in Excavations at Seila, Egypt, C. Wilfred Griggs, ed. (Provo, UT: Religious Studies Center, Brigham Young University, 1988), 76.

${ }^{43}$ Swelim, "An Aerial View," 647-653; Nabil Swelim, "Reconstructions of the Layer Monument of Snfrw at Seila," in Echoes of Eternity: Studies Presented to Gaballa Aly Gaballa, Ola El-Aguizy and Mohamed Sherif Ali, eds. (Wiesbaden: Harrassowitz Verlag, 2010), 39-56.
} 
During this season, a few angled, smooth facing stone fragments were found. At some point, more were found but it is not clear when. At least one was found near the northern porch on the north side of the pyramid, and two were found on the eastern side, one just north of the eastern porch and one just south. ${ }^{44}$ These angled facing stones are in addition to fragments of facing stones which we cannot tell whether or not were angled. Fragments of facing stones were discovered in the northwest corner of the pyramid. Four facing fragments were found near the outside edge of the northern porch/chapel, labeled Stone Objects B, C, D, and H. These could have been for the facing of the pyramid or instead could have faced a chapel if something covered the porch pavement on the northern side. Four examples of outer casing stones were found near the eastern chapel. Stone Object A was found south of the chapel/porch, a fragment labeled as being part of object $\mathrm{H}$ was found south of the chapel/porch, and two pieces of $\mathrm{H}$ were uncovered north of the chapel/porch. ${ }^{45}$ Of the pyramid facing stones, Swelim wrote "the dressed limestone of the outer facing was bound by a hard white gypsum mortar. Its foundation was built over steps dug in the gravel to reach an all-round level for the pyramid base." 46 The 2018 season rediscovered some limestone blocks that had natural gypsum infusions on the surface, causing them to look almost as if they were burnished grey granite. We cannot tell if this is the kind of gypsum mortar to which Swelim referred.

[page 57]

All of these facing stones, especially the angled ones, indicate that the pyramid was likely originally fully faced with angled stones and was thus probably a true pyramid. It is possible that the facing was never finished, though it had been for all the rest of the pyramids built at the time (for dating the pyramid see below) and plundering of facing stones is common. ${ }^{47}$ Thus, while we cannot be sure, it is likely that this was a true pyramid akin to its early $4^{\text {th }}$ Dynasty

\footnotetext{
44 These positions are based on personal communications with Wilfred Griggs, studying drawings made at the time of excavation, and at least one angled stone still visible on the southern side of the eastern porch. ${ }^{45}$ Nabil Swelim, "The Architecture: minor step pyramids or archaic ben bens," accessed May 2019, http://nabilswelim.com/downloads/3.pdf.pdf, 12-13.

${ }^{46}$ Nabil Swelim, "The Layer Monuments," 1, accessed May 2019, http://nabilswelim.com/downloads/LM\%20for\%20enc\%20cancelled.pdf.

${ }^{47}$ Swelim, "The BYU Expedition to Seila," 1 and fn 2, felt that the defacement of the facing stones happened in the $5^{\text {th }}$ Dynasty. His only evidence for this was that other $4^{\text {th }}$ Dynasty pyramids had been plundered during the $5^{\text {th }}$ Dynasty.
} 
contemporaries. We are currently undertaking a number of analyses that will further address this question and will be part of a future full publication of the pyramid.

It seems likely that the upper facing stones were removed fairly early on, exposing the mudstone blocks of the upper layers of the pyramid to erosion. Flakes, or spalls, from these blocks fell around the pyramid over time, creating a pile over a meter thick in many areas, even up to 2 meters in places. The lower facing stones were removed much later since the falling flakes of the mudstone fell around where these stones once lay, leaving a negative impression of their presence. $^{48}$

Among the most important finds were objects at the center of the northern wall and others at the center of the eastern wall. A small porch, or "naos" as Swelim first called it, ${ }^{49}$ was found on the northern side of the pyramid. Mud-bricks were laid squarely on a level gravel base to create the porch. On the outermost (northern) edge the remains of a brick wall were found, 4.4 meters from the pyramid. ${ }^{50}$ This raises the possibility that the porch had been enclosed, forming a ritual chapel. The aforementioned basalt block found by Borchardt was likely part of this structure, possibly from the floor if it is somewhat similar to Khufu's pyramid temple. Early on, Griggs referred to this structure and/or the pavement on the eastern side as "the remains of a temple pavement," and called the artifacts found there "temple artifacts," though he did not use this terminology for long. ${ }^{51}$ Further dimensions of the porch were not [page 58] recorded, and the bricks were removed during the archaeological process of determining whether there was something beneath them, thus making it impossible to recover the dimensions via re-excavation. It is hoped that as we continue the search for excavation notes that perhaps we may one day find these dimensions. Based on the architectural drawings, the porch/chapel was likely about a meter going from east to west and half a meter going from south to north.

A floor surface was made atop the bricks by laying down powdered limestone mixed with sand. ${ }^{52}$ On or near this floor, the remains of a stone table and thirty fragments of a small stone

\footnotetext{
${ }^{48}$ Swelim, “An Aerial View,” 6.

${ }^{49}$ Ibid.

${ }^{50}$ Nabil Swelim, "Reconstructions of the Layer Monument of Snfrw at Seila," 41.

51 C. Wilfred Griggs, Marvin C.J. Kuchar, Mark J. Rowe, and Scott R. Woodward, "Identities Revealed: Archaeological and Biological Evidences for a Christian Population in the Egyptian Fayum," in The Ancient Near East, Greece, and Rome, T. W. Hillard, R. A. Kearsley, C.E. V. Nixon, and A. M. Nobbs, eds. (Grand Rapids: Eerdmans, 1998), 1:82.

52 Swelim, “An Aerial View," 648.
} 
statue were found. ${ }^{53}$ In 1987 a somewhat unique libation altar was also found. ${ }^{54}$ A more detailed description of the altar and statue are in another chapter in this volume. At this time it was determined that the statue was made of a very white travertine, and it was suspected that the altar was as well. Travertine is often referred to as "Egyptian Alabaster," and is a calcium-carbonate stone.

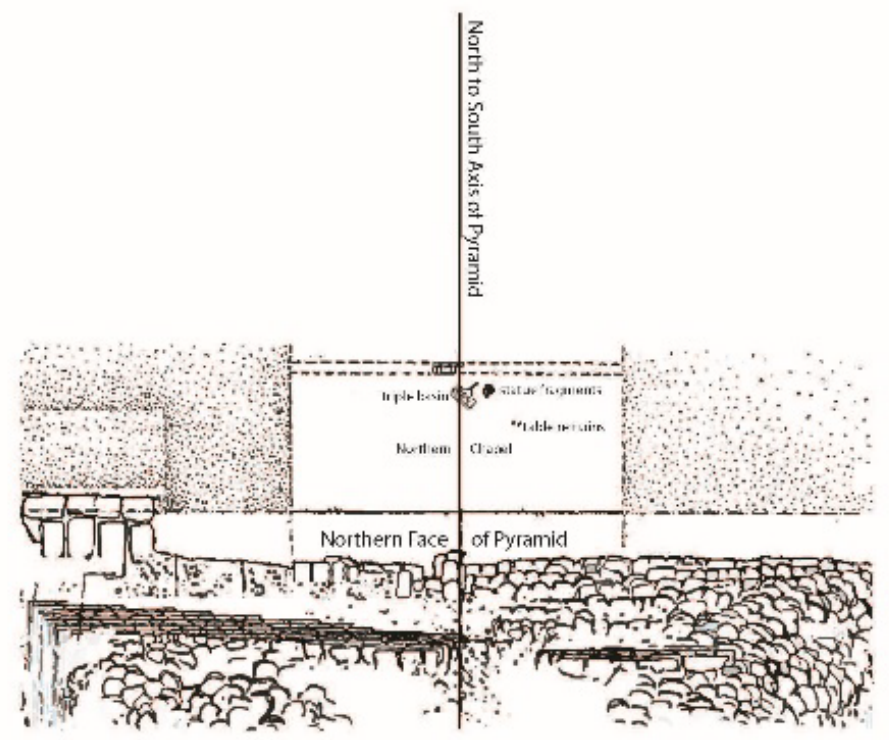

Figure 3. 2: diagram of the central part of the northern face of the pyramid. Diagram by Kathryn Stubbs [found on page 59]

Some plant material was also found in this area. Recent analysis (see the chapter in this volume) has determined that it was from the Cyperus family, likely one of two forms of sedge tubers. ${ }^{55}$ Though we cannot be sure, it is hard to picture why such vegetation would be present if it were not part of a ritual offering, possibly with symbolic significance because it is a sedge. Because members of the Cyperus family were used as food in Egypt, ${ }^{56}$ it seems probable that the vegetable remains were part of a food offering that accompanied the liquid offerings we know

\footnotetext{
53 Ibid.

${ }^{54}$ C. Wilfred Griggs, "General Archaeological and Historical Report of 1987 and 1988 Seasons at Fag el Gamous," in Actes du IVe Congres copte, 1988. Tome I: Art et archéologie, eds. Marguerite Rassart-Debergh and Julien Ries (Louvain: Peeters, 1992), 195; Swelim, "The BYU Expedition to Seila," 6; and I.E.S. Edwards, "The Pyramid of Seila and its Place in the Succession of Snofru's Pyramids," in Chief of Seers: Egyptian Studies in Memory of Cyril Aldred, E. Goring, N. Reeves, and J. Ruffle, eds. (London: Routledge, 1997), 89.

55 See the botanical report in this volume.

${ }^{56}$ Mary Anne Murray, "Fruits, Vegetables, Pulses and Condiments," in Ancient Egyptian Materials and Technology, Paul T. Nicholson and Ian Shaw, eds. (Cambridge: Cambridge University Press, 2000), 636-37.
} 
took place in that area. The remains of at least three $4^{\text {th }}$ Dynasty ceramic vessels were also found, though not enough information was recorded about these vessels to determine more about their nature or use. They certainly could have been part of food offerings if such a thing took place at this ritual structure.

[page 59]

Two round topped stelae were found on the eastern side. The extant remains of one is just over a meter tall $(1.3 \mathrm{~m}),{ }^{57}$ and the other is almost two meters, though they have both clearly been broken. The shorter stela is $0.6 \mathrm{~m}$ wide and $0.37 \mathrm{~m}$ thick. ${ }^{58}$ The taller stela was uninscribed, though it is broken enough that we cannot be certain that it did not once carry an inscription. The shorter stela contained the inscribed Horus name neb-ma'at, and the Nsw-bity (King of Upper and Lower Egypt) name "Snefru." The identity of the pyramid's builder had finally been revealed. ${ }^{59}$ The discovery that the Seila Pyramid had been built by [page 60] Snefru caused some to begin to rethink the history of the Fayoum during the Old Kingdom. ${ }^{60}$

\footnotetext{
${ }^{57}$ In a letter to I.E.S. Edwards written by C. Wilfred Griggs, April 5, 1990, in the British Museum archives, Griggs lists the stela as being 1.4 meters tall. It is possible that some of it was broken during transport, or that this measurement was just a little off.

${ }^{58}$ Ibid.

${ }^{59}$ Swelim, "Seila," 1, felt that this was the first of Snefru's pyramids. If it was begun while the Meidum Pyramid was being finished, its size dictates that it would probably have been finished first.

${ }^{60}$ See Andrzej Ćwiek, "Fayum in the Old Kingdom," Göttinger Miszellen 160 (1997): 17; and the chapter on the history of the Fayoum in this volume.
} 


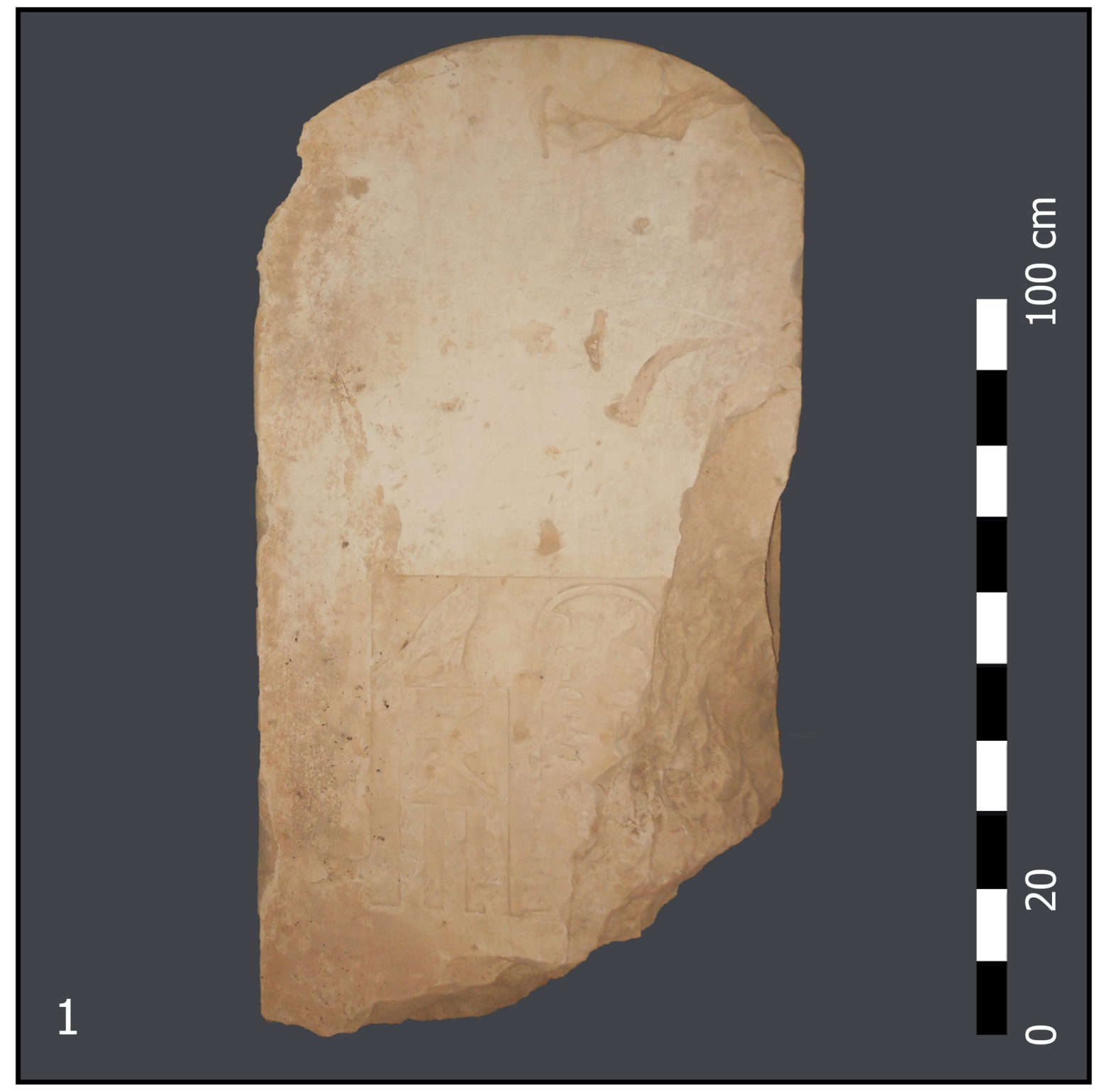

Figure 3.3: The inscribed stela, photo by Sayed Sa'ad. [found on page 60]

Near these stelae, several fragments of travertine were discovered. They were of a similar composition to the libation altar found on the northern side. This suggests that some kind of altar was present on the eastern side as well, though we cannot be sure. 


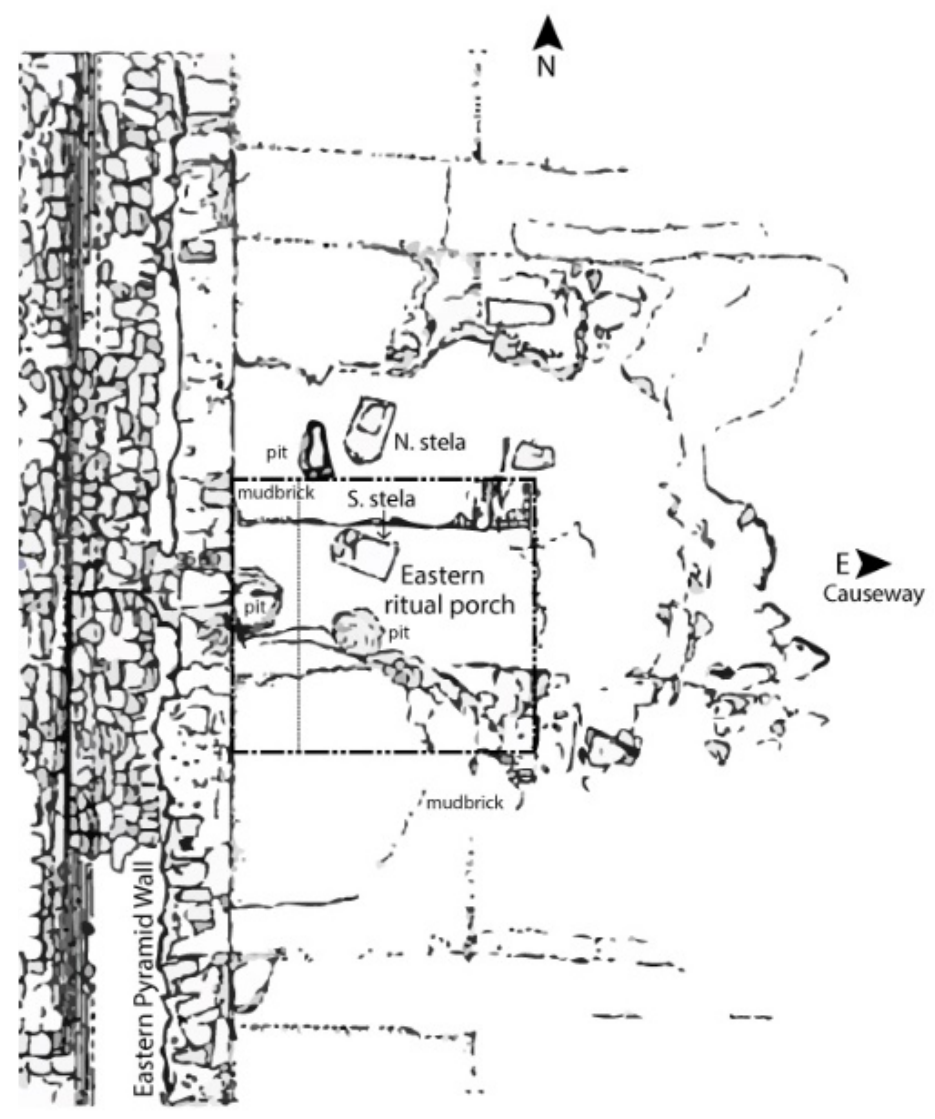

Figure 3.4: Diagram of the eastern face of the pyramid. Diagram by Kathryn Stubbs. [found on page 61]

Even with the extensive excavation conducted that season. the north and west outer walls were not fully cleared, so Swelim felt they still could not determine the size of the pyramid. ${ }^{61}$

[page 61]

\section{The 1988 Season}

During the next season, further excavation continued at the pyramid from February 7-March 3, 1988. Besides those who had participated before, the team was joined by more architects from Homsey's firm, namely Melissa Harris, James McLane and Charles Davis, another founding partner of the firm. I.E.S. Edwards also visited the site and worked with the excavation team that season, [page 62] and continued to consult with the team for many years following. ${ }^{62}$ John

\footnotetext{
${ }^{61}$ Swelim, "The BYU Expedition," 5.

${ }^{62}$ Correspondence between Edwards and Griggs about the pyramid as late as 1990 are held in the British Museum archives.
} 
Rutherford, an engineer from San Francisco, also came. While he did not publish the results of his study, Rutherford determined that the pyramid lay due west of the Meidum Pyramid and was at a similar elevation to the top of that seemingly sister structure. ${ }^{63}$

During this excavation season, which focused solely on the eastern side, a mud-brick porch or pavement extending along the length of the eastern side of the pyramid was found. It appears that a layer of bricks was laid down on top of a layer of compacted sand fill and mud packing and seems to have abutted directly against where the facing stones of the pyramid would have lain. Some sort of structure seems to have formed a wall that joined the porch floor to the pyramid, though only four stretcher and three headers abutting the pyramid now remain of this structure, consequently making it impossible to determine more about it. The bricks in both the north and east porches measured $22 \times 11 \times 7.5-8 \mathrm{~cm} .{ }^{64}$ On the eastern side, these mud-bricks were laid on an artificially built up terrace that leveled the ground extending to the east side of the hill somewhat before the landscape fell steeply down to the wadi. Much of this terrace was covered with gravel which served as a level base for most of the bricks. ${ }^{65}$ The terrace itself was built largely of chippings from the same kind of stone the pyramid was made of (labeled limestone initially, but recent geological analysis reveal it to be mudstone, though some of the chips seen in old photographs do appear to be limestone, probably from facing stones). Presumably, these chips were created from the quarrying process. The pavement extended east from the pyramid wall for about three more meters.

The porch was not perfectly rectangular, but seems to have conformed to the contours of the hill. It was about $3 \mathrm{~m}$ wide on its northern side and grew wider as it moved south. Because the hillside is not level in this area, with a rise occurring in the center of eastern side, the gravel base could not provide a full ability to level the terrain. In order to remedy this, the pavement was further leveled by inserting two courses of masonry on the northern side and one course on the southern. ${ }^{66}$ As a result, this pavement, which was called a "court" [page 63] in the earliest

\footnotetext{
${ }^{63}$ Personal communication with Wilfred Griggs, to whom Rutherford reported the results of his work.

${ }^{64}$ Homsey's drawings preserve these measurements.

${ }^{65}$ Swelim, "Reconstructions of the Layer Monument," 42-44.

${ }^{66}$ Swelim, “An Aerial View," 650.
} 
reports, was "almost perfectly horizontal," or level. ${ }^{67}$ Seismic settlement over time could easily account for any aberrations in this assertation .

In the center of this paved porch, a kind of chapel with the remains of a mudbrick wall around it extended out another 1.57 meters. ${ }^{68}$ The remains do not allow us to determine the original height of this wall, and neither Swelim's nor Griggs' publications inform us of how many courses still stood when they excavated. None of it remains now; it must have been disassembled during excavation. There is some confusion about the width of this chapel since the preliminary report filed at the end of the 1988 season describes it as consisting of two rows of bricks running parallel eastward, ${ }^{69}$ but Swelim's scaled drawings show the chapel to be about five meters wide. ${ }^{70}$ While the bricks have all been removed now, the 2018 re-excavation revealed a backfilled space that matches most closely Swelim's measurements.

During these excavations, they uncovered five holes that had been carved into the bedrock along the eastern porch. ${ }^{71}$ Griggs noted that the diameters of the holes were enlarged below the surface of the ground, ${ }^{72}$ which would make them similar to holes that held pots at the Bent Pyramid's "Valley Temple," and Red Pyramid's Valley Temple, ${ }^{73}$ suggesting that the Seila holes may have been created for the same reason. Presumably, offerings were made in these bowls.

Further refinement of this picture was made possible by re-excavation in the 2018 season. A sixth hole was uncovered. Two of the six holes lie in a straight axis south of the central chapel. Only one of the two holes on the southern side was excavated in 2018 because the hole visible in pictures that lay even further south was outside of the area that we were able to excavate during this season. These are the only two holes for which we have good photographs from the earlier excavation seasons. These photos show that both were bell shaped and [page 64] fairly uniform in size. Measurements for the hole that was unearthed in 2018 show that "the top of the pit is

\footnotetext{
67 "Preliminary Report for the Brigham Young University Fag El Gamous, Seila Excavation, Jan. - March, 1988," as filed with the Egyptian Antiquities Organization, 2. We are grateful to Yasmin Omar and Rasha Elhadad, Ministry of Antiquities inspectors who searched through Ministry of Antiquities archives to find this and other reports.

${ }^{68}$ Swelim, "Reconstructions of the Layer Monument," 44, and information from the 2018 excavation season.

69 "Preliminary Report for the Brigham Young University Fag El Gamous, Seila Excavation, Jan. - March, 1988," as filed with the Egyptian Antiquities Organization, 2.

${ }^{70}$ Swelim, "Reconstructions of the Layer Monument," 44.

${ }^{71}$ Personal correspondence with Wilfred Griggs.

${ }^{72}$ Ibid.

${ }^{73}$ Ahmed Fakhry, "The Excavation of Snefru's Monuments at Dashur: Second Preliminary Report," ASAE 52 (1952): 574.
} 
ovoid in shape, measuring $25 \times 35 \mathrm{~cm}$ in size. At its widest point inside the pit, it is $35 \times 42 \mathrm{~cm}$ in size. Its slightly rounded base narrows to $21 \times 26 \mathrm{~cm}$, and it is $42 \mathrm{~cm}$ deep. The sides of not only this pit, but all the subsurface pits, consist of the hard bedrock material." ${ }^{, 4}$ No artifacts were recovered from the pit, but two thin slabs of limestone were wedged into the northern part of this cavity at its widest point. One of these exhibited a surface of glossy gypsum infusion. As noted above, these two holes likely held pots or bowls. Because the libation altar was on the north side it is reasonable to postulate that food offerings may have been made in these bowls, which would work in tandem with the liquid offerings as has been noted in other settings. ${ }^{75}$

In contrast to how earlier excavators had remembered the other holes, they were not rounded in shape, nor were they in a straight line with each other. The 2018 re-excavation not only found an additional hole, but revealed that these remaining four holes, just north of the central chapel, formed an almost perfect square. These four holes had generally straight walls. They were of varying width and depth, though the erosion of the surface in that area makes it difficult to determine how much they now vary from their original depth. Moreover, they are placed in an area where the ground slopes, which may account for their varying sizes. In any case, the shape and position of the four holes makes it appear that they were intended to hold four posts which could have supported some kind of roof.

Many small stone fragments were found in the area of the eastern central chapel, though it is no longer possible to determine what they are fragments of. Additionally, Swelim reports finding a large slab of stone, Stone Object F, he felt may have been the roof of a chapel for a model boat. The slab was very large, measuring $75 \mathrm{~cm}$ long, $67.5 \mathrm{~cm}$ wide, and $45 \mathrm{~cm}$ thick. ${ }^{76}$ Swelim also found a small wooden oar, such as are included in model boats. It is $14 \mathrm{~cm}$ long, $2 \mathrm{~cm}$ wide at the blade, and was painted white with traces of red pigment. ${ }^{77}$ It was the presence of this oar that gave rise to the theory of a model boat, and thus a model boat chapel. ${ }^{78}$ Yet it is quite possible that this large carved stone could have been used for something else.

\footnotetext{
${ }^{74}$ This description was provided by Deborah Harris in our preliminary excavation report.

${ }^{75}$ Regina Hölzl, "Libation Basins from the Old to the New Kingdom: Practical Use and Religious Significance," in L'Acqua Nell'antico Egitto: Vita, Rigenerazione, Incantesimo, Medicamento, Alessia Amenta, Michela Luiselli, and Maria Novella Sordi, eds. (Rome: L’Erma di Bretschneider, 2005), 313.

${ }^{76}$ Swelim, "Reconstructions of the Layer Monument," 41-47.

${ }^{77}$ Personal observation.

${ }^{78}$ Swelim, "Reconstructions of the Layer Monument," 41.
} 
[page 65]

Additionally, three pits were found around or under the porch. Their purpose is unknown. Swelim felt that two of them may have been where the stelae stood. ${ }^{79}$ A steep embankment of stonework was encountered at this point. Based on this and a sondage made by Lesko in the 1981 season, ${ }^{80}$ the team supposed that a causeway had been found, though it would be several more years before they excavated the causeway. Several sondages were also made in the eastern wadi, but, besides the evidence of the causeway and a few loose pottery sherds, no evidence was found for anything else in the area. ${ }^{81}$

During this (the 1988) season, in the space next to the pyramid, covered by falling spalls from the exposed rock that eroded due to the harsh climate, the remains of a cord basket and a small wooden box with a sliding lid were found. Swelim dated the box to the Middle Kingdom, which suggests that there was some kind of activity there in the Middle Kingdom (as there was at the Bent Pyramid). It would follow that the structure lay undisturbed for long enough afterwards that the Middle Kingdom layer was slowly covered by natural erosion. ${ }^{82}$ While Swelim published pictures of these objects, ${ }^{83}$ their whereabouts are currently unknown and we cannot verify the dating of the box. On top of the rubble that covered these objects were the remains of what was judged to be a $3^{\text {rd }}$ or $4^{\text {th }}$ century amphora, as well as a Philomator coin. Though we can only now examine a grainy black and white photograph of the amphora, its appearance is more like a Ptolemaic vessel, based on the placement of the handle and shape of the rim. This would make it match more closely the date of the coin. Interestingly, in the 2018 season in the loose sand on the descent from the pyramid another ancient coin was found, containing the double eagle of Ptolemy VI. The three coins found in the pyramid area suggests that there was activity around the pyramid in the Ptolemaic era, supporting Lesko's conclusion that plundering of the blocks of the pyramid had taken place during the Ptolemaic era. ${ }^{84}$

\footnotetext{
${ }^{79}$ Swelim, “An Aerial View," 650.

80 "Preliminary Report for the Brigham Young University," 2.

81 Ibid.

${ }^{82}$ Swelim, "The BYU Expedition to Seila," 1.

${ }^{83}$ Nabil Swelim, "Seven Layer Monuments of the Early Old Kingdom, Forthcoming," 34, accessed May 2019, http://nabilswelim.com/downloads/MSP Pre.pdf.pdf. Confirmation of the dating is not possible at this time.

${ }^{84}$ Lesko, "Seila 1981," 226.
} 
Having uncovered a previously unknown step of the pyramid made it clear that it was larger than had originally been thought. At this time, Swelim estimated that the length of the base of the pyramid was about $30 \mathrm{~m} .{ }^{85}$ Griggs, [page 66] however, estimated it was about $25 \mathrm{~m},{ }^{86}$ though he would elsewhere say that it was $25 \mathrm{~m}$ from the center of the pyramid to its furthest corner and the sides were about $35.5 \mathrm{~m}$ long, presumably meaning that this would be the length with the casing stones intact. ${ }^{87}$ Both were short of what later engineers would find, though Swelim was close and Griggs' later estimate was very close. Clearly more work needed to be done.

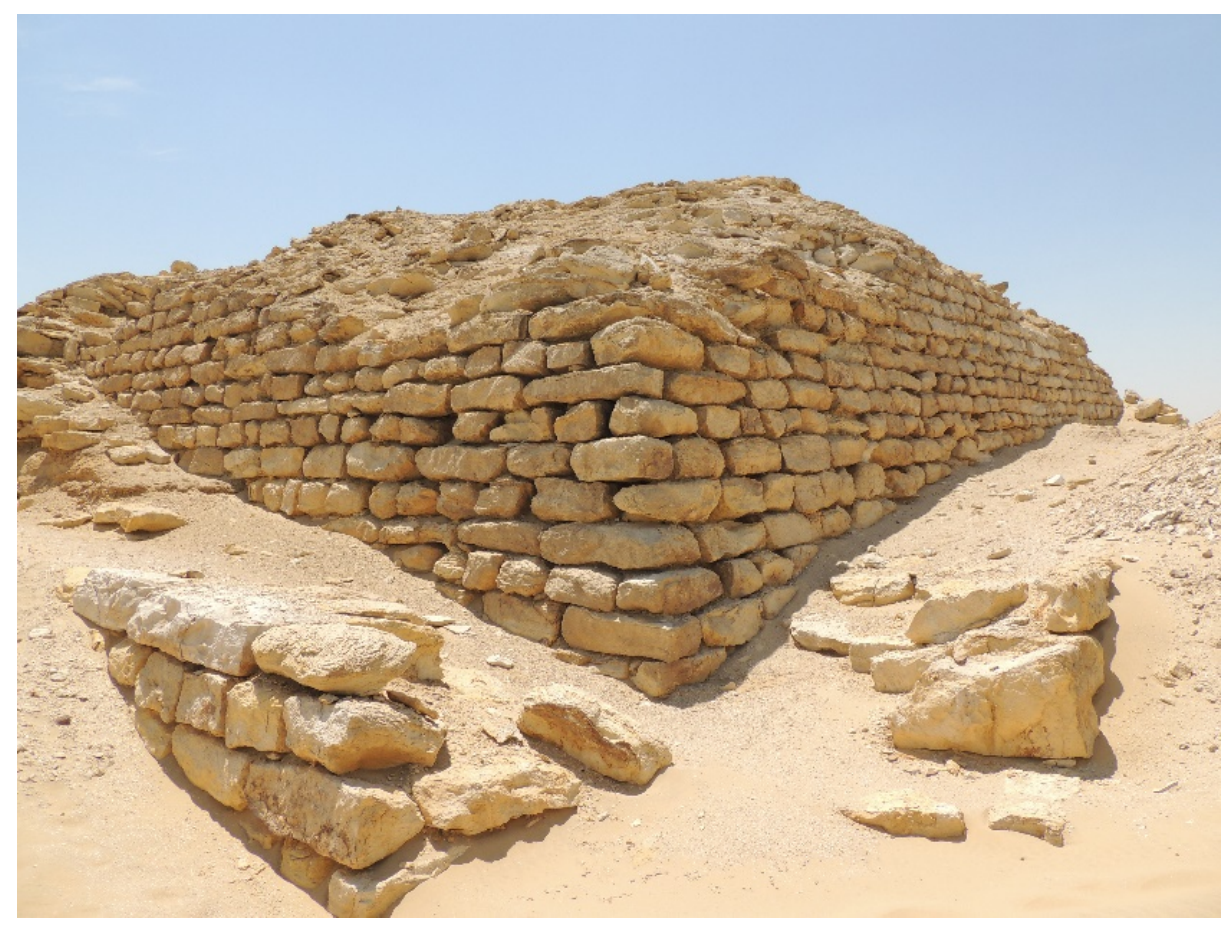

Figure 3.5: the outermost steps of the pyramid visible at the northwest corner. Photo by Kerry Muhlestein [found on page 66]

\section{Later Work}

In 1992, at the behest of the Egyptian Antiquities Organization, the two stelae were moved to the excavation's storage magazine. The preliminary report filed for this year states that in the process of moving the stelae they discovered yet [page 67] another step, lower than those

\footnotetext{
${ }^{85}$ Swelim, "Reconstructions of the Layer Monument," 56.

${ }^{86}$ Personal communication.

${ }^{87}$ Griggs to Edwards, 5 April 1990, in British Museum Archives. These measurements as recorded in this letter are referred to by Edwards in I.E.S. Edwards, "The Pyramid of Seila and its Place in the Succession of Snofru's Pyramids," 92.
} 
exposed thus far and still buried. They also report having discovered mudbrick paving for a temple courtyard on the east side of the pyramid. ${ }^{88}$ This is somewhat confusing because the 1988 report also spoke of the pavement for a temple courtyard and described it in some detail. In any case, these discoveries convinced the team that they needed to do more work on the eastern side of the pyramid.

The work was undertaken during the 1995 season. Because Nabil Swelim, who was a detailed note taker, was not present for this season, we have less information available for it than for the earlier seasons. It was in this year that another key element of the pyramid was fully uncovered. Extending straight east from the center of the pavement, connecting to the small chapel, is a causeway made of large limestone blocks. The causeway is not evenly preserved, but its original measurements can still be determined. Because either precise measurements were not recorded or have been lost, we focused on obtaining this information during re-excavation in the 2018 season. The dimensions of the causeway are $7 \mathrm{~m}$ long by $8.4 \mathrm{~m}$ wide. Downslope angles range from 35 degrees along the steepest part of the structure. Near the top, the angle shallows to 22 degrees as it nears the platform/porch area. The overall angle was originally estimated to be 29 degrees. ${ }^{89}$ The causeway has a clear ending, with the bottommost blocks, which run perpendicular to the rest of the stones of the causeway, anchored into a lip carved into the bedrock. This allows those lowest stones to serve as an anchor for the rest of the causeway, preventing any of its stones from slowly working their way downhill as gravity inexorably pulls on them.

\footnotetext{
${ }^{88}$ C. Wilfred Griggs, "Preliminary Report of the Brigham Young University 1992 Excavation Season,” as filed with the Egyptian Antiquities Organization, 1. We are grateful for Rasha Elhadad and Yasmin Omar, inspectors for the Ministry of Antiquities, for helping us obtain this report.

${ }^{89}$ Swelim, "Reconstructions of the Layer Monument," 44.
} 


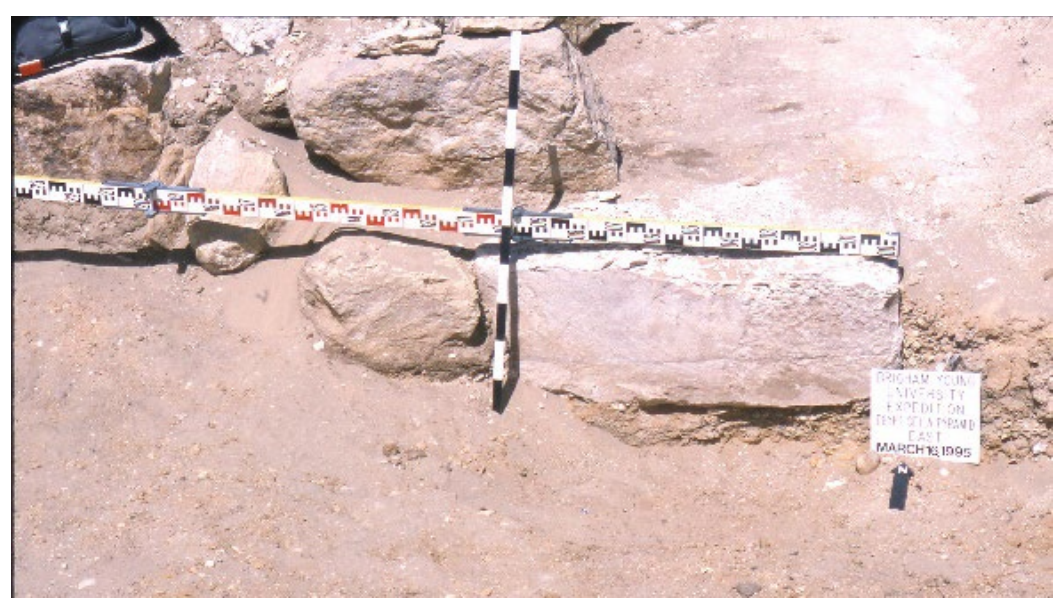

Figure 3.6: An anchoring stone in the causeway. Photo courtesy of Revell Phillips. [found on page 68]

On the south-eastern corner a small foundation deposit jar was found, butted up against the large anchor stone. Inside the jar black and red dirt had been placed in 2 distinct layers. The intention of drawing on the symbolism of Black Land and Red Land is clear. No traces of a structure at the bottom of the causeway have been found; there does not appear to be any kind of Valley Temple.

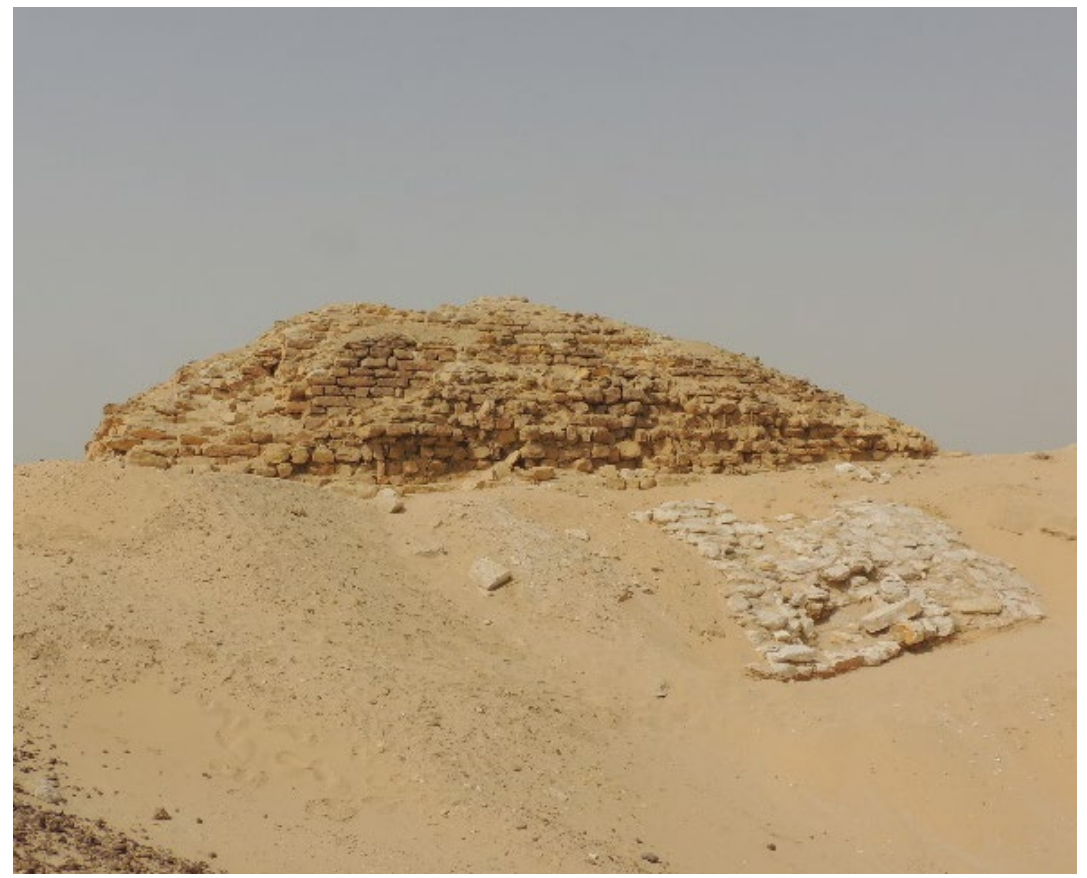

Figure 3.7: The eastern side of the pyramid with the causeway exposed. Photo by Kerry Muhlestein [found on page 68]

In the 2009 season, a team of three engineers and a student from BYU conducted GPS mapping of both the Seila and Meidum Pyramids, in addition to producing a topographical map of the 
necropolis. Harold Mitchell, Brent Benson, Todd Osborn, and Alexander Lovett, began to produce a detailed structural analysis of the Seila Pyramid. Since that time Benson has continued the [page 68 includes figures 3.6 and 3.7] [page 69]work, and, with the use of sophisticated software, has been able to determine with impressive accuracy the original size and structure of the pyramid, finding it to be larger and much higher than was originally thought. By looking at the third step of the pyramid, which is the step with the most complete and visible remains, he identified all four corners of the pyramid. Performing a best fit analysis of these corners, he was able to determine that the pyramid was oriented 0.45 degrees west of true north, or at 359.55 degrees, meaning that it was less than half a degree off of perfect cardinal orientation. Preliminary estimates indicate that the fully cased pyramid was over 36 meters at the base and nearly 8 stories tall $(23.4 \mathrm{~m})$. Full details of architectural features will be published in a more comprehensive volume in the future. Benson has also done a great deal of work on the structural relationship between the Seila and Meidum Pyramids, which will also be published in due time. In 2014, further geological analysis of the stones of the pyramid was performed by Ronald Harris of the BYU Department of Geological Sciences. While all earlier reports described the pyramid as having been built of limestone, this was largely, though not completely, inaccurate. Most of the pyramid is constructed of blocks less than one meter in any dimension that consist mostly of mudstone with some interlayers of siltstone and limestone. The blocks are cemented together using a mud mortar with sand and rock fragments less than $4 \mathrm{~cm}$ in diameter. Of course the different types of stones in the pyramid erode at varying rates. This differential erosion is in the process of making the pyramid unstable. Mortar mud preferentially erodes out from under the mudstone blocks, which are much more indurated than the mortar, and thus form overhangs. Many of the overhanging mudstone blocks are collapsing from the structure. 


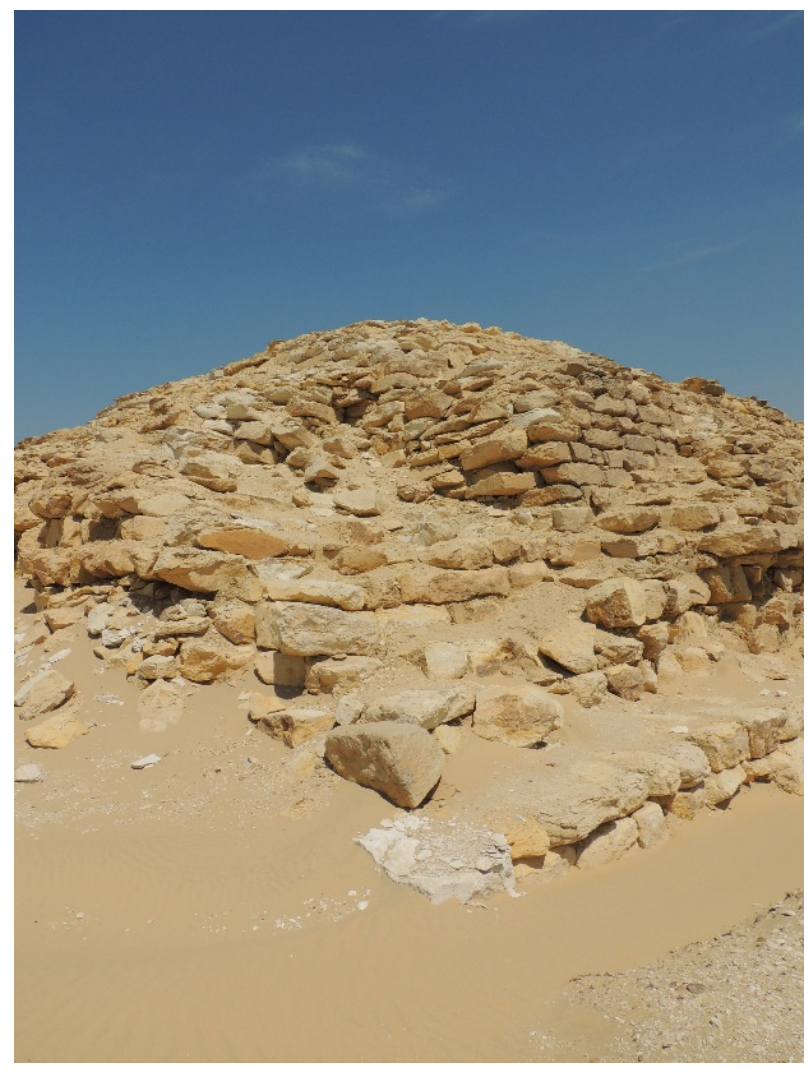

Figure 3.8: The southeast corner of the pyramid, where erosion and resulting overhangs are visible. Photo by Kerry Muhlestein [found on page 70]

Limestone, confirmed by XRF analysis, is found in blocks lying near the pyramid and included as blocks within it or interlayers within mudstone blocks. The limestone is the material most resistant to erosion of those materials used to construct the pyramid. Perhaps this is why the builders of the pyramid used it as a facing stone, which would prevent the rapid erosion of the clay-rich materials, such as the mudstone blocks, which lay under the limestone facing.

Mutually perpendicular natural fractures encrusted with hematite that are found throughout the mudstone blocks indicate that many of the blocks used to construct the pyramid were likely already broken into rectangular pieces before quarrying. Many such blocks are visible in outcrops surrounding the pyramid. ${ }^{90}$

[page 70]

\footnotetext{
${ }^{90}$ For this analysis and description we are indebted to Ronald Harris, and is largely derived from Kerry Muhlestein, Giovanni Tata, Ronald Harris, Deborah Harris, R. Paul Evans, Lincoln Blumell, Catherine Taylor, Brian Christensen, John Gee, Kristin South, Joyce Smith, Casey Kirkpatrick, and Manal Saied Ahmed, "The Fag elGamous 2014 Excavation Season," Annales du Service des antiquités de l'Egypte, 2014.
} 
The 2018 season, completed just days before this was written, was conducted by Kerry Muhlestein, Deborah Harris, and Bethany Jensen, with some assistance from Kristin South. Additionally, our skilled foreman, Gabr abd il-Ati, was key in accomplishing the work. As was noted above, the causeway was re-excavated, as was some of the paved porch and the holes on the eastern side. [page 71] Some details of this work have been included in this article, but more will be presented in the future.

\section{$\underline{\text { Ritual Ramifications }}$}

Some key similarities between the Seila and Meidum Pyramids have already been noted, explored and preliminarily published. ${ }^{91}$ In particular, the presence of cultic elements on both the northern and eastern side is important in pyramid history. Before Snefru, pyramids largely had a north-south axis as their primary orientation. ${ }^{92}$ Snefru's Dashur pyramids had a greater east-west axis as their primary orientation, ${ }^{93}$ the details of which will be discussed more fully below. Snefru's son, Khufu, built the Great Pyramid and set a pyramid complex standard that would be closely followed thereafter, though most of what he did was based on his father's work at Dashur. The Meidum Pyramid is typically viewed as a transitional pyramid, standing programmatically between pyramids that pre-dated Snefru and the architectural program of the Dashur pyramids and those that followed. ${ }^{94}$ Hence pyramids with an east-west orientation are often referred to as "post-Meidum" pyramids, though it should be noted that the Dashur Pyramids are also somewhat transitional.

The Meidum Pyramid had a north-south oriented burial chamber and a northern entrance, like the pyramids before it. ${ }^{95}$ Yet the Meidum Pyramid had something else: a temple structure erected

\footnotetext{
${ }^{91}$ Most of what is presented below was also discussed in another article. See Kerry Muhlestein, "Transitions in Pyramid Orientation: new evidence from the Seila Pyramid," Studien zur Altägyptischen Kultur 44/1 (2015): 249258 , tables $37-38$

${ }^{92}$ Ann Macy Roth, "Social Change in the Fourth Dynasty: The Spatial Organization of Pyramids, Tombs, and Cemeteries," JARCE 30 (1993): 33.

${ }^{93}$ This is often thought to be due to a rise in the emphasis of the sun cult. For example, see Dieter Arnold, The Monuments of Egypt. An A-Z Companion to Ancient Egyptian Architecture, (London: I.B. Tauris \& Co Ltd., 2009), 183. But see James P. Allen, The Ancient Egyptian Pyramid Texts, (Atlanta: SBL Press, 2005), 12, about a shift to south-north motion rather than eastwards in the pyramids, related to the Northern Stars.

${ }^{94}$ Roth, "Social Change in the Fourth Dynasty," 33. Arnold, The Monuments of Egypt, 145, writes that Meidum consisted originally of a north-south axis, but was converted to an east-west axis.

${ }^{95}$ G. B. Johnson, “The Pyramid of Meidum Part One," KMT 4/2 (1993): 66; Miroslav Verner, The Pyramids: Their Archaeology and History, Steven Randall, trans. (London: Atlantic Books, 2001), 162.
} 
on the eastern side of the pyramid. ${ }^{96}$ [page 72] This pyramid temple ${ }^{97}$ also contained two uninscribed stelae ${ }^{98}$ and a crude offering table. ${ }^{99}$

From the temple a causeway extended, running eastward. ${ }^{100}$ While large mud bricks have been found at the end of this causeway, nothing that suggests a valley temple has been unearthed. ${ }^{101}$ The new structure suggests that while the elements usually associated with burial-entrance to the pyramid and the chamber-were still oriented north-south, ritual activity was centering on the east. The Dashur Pyramids, also built by Snefru, continued the practice of creating an entrance on the northern side. ${ }^{102}$ Yet the Bent Pyramid, compounding its dual-orientation, actually has an entrance on both the north and west sides. ${ }^{103}$ Both entrances lead to chambers with a north-south orientation. A pyramid temple is also present on the east side of this pyramid. ${ }^{104}$ It was small in comparison to later $4^{\text {th }}$ Dynasty pyramid temples, yet larger than the one built at Meidum. ${ }^{105}$ Two inscribed stelae were erected here, as well as an altar. ${ }^{106}$ A causeway leads out from the complex, ${ }^{107}$ but instead of running straight east [page 73 ] from the pyramid temple, it begins on

\footnotetext{
${ }^{96}$ George B. Johnson, “The Pyramid of Meidum Part Two,” KMT 5/1 (1994): 74.

${ }^{97}$ Often referred to as a mortuary temple.

${ }^{98}$ W.M. Flinders Petrie, Medum (London: David Nutt, 1892), 8; Alan Rowe, "The Eckley B. Coxe, Jr., expedition excavations at Meydum, 1929-30," Penn. Univ. Mus. Journal 22/1 (1931): 32; and Martin Isler, Stick, Stones, and Shadows: Building the Egyptian Pyramids (University of Oklahoma Press, 2001), 125.

${ }^{99}$ Ali el-Khouli, Meidum, The Australian Centre for Egyptology: Reports 3, Geoffrey T. Martin, ed. (Sydney, Australia: Australian Centre for Egyptology, 1991), 13; Rowe, "The Eckley B. Coxe, Jr., expedition," 32; Petrie, Medum, 8.

${ }^{100}$ W.M. Flinders Petrie, Ernest Mackay, and Gerald Wainwright, Meydum and Memphis (III) (London: School of Archaeology in Egypt, 1910), 6. Stadelmann, "Snofro - Builder and Unique Creator of Pyramids of Seila and Meidum," 37.

${ }^{101}$ Nabil Swelin, Some Problems on the History of the Third Dynasty, (Alexandria: The Archaeological Society of Alexandria, 1983), 84.

${ }^{102}$ See Ahmed Fakhry, The Pyramids, (Chicago: University of Chicago Press, 1969), 93; and I.E.S. Edwards, The Pyramids of Egypt, $5^{\text {th }}$ ed. (Baltimore: Penguin Books, 1993), 80-81.

${ }^{103}$ Ibid. Also Alexander Badawy, A History of Egyptian Architecture Vol. 1: From the Earliest Times to the end of the Old Kingdom, (Giza: Sh. Studio Misr, 1954), 134; and Hadyn R. Butler, Egyptian Pyramid Geometry,

(Mississauga, ON: Benben Publications, 1998), 151.

${ }^{104}$ Philip J. Watson, Egyptian Pyramids and Mastaba Tombs of the Old Kingdom, (Essex: Princes Risborough, 1987), 26; and Ahmed Fakhry, The Monuments of Sneferu at Dashur, (Cairo: General Organization for Government Printing Offices, 1959), 1:39.

${ }^{105}$ Herbert Ricke, "Baugeschichtlicher vorbericht über die kultanlagen der südlichen pyramide des Snofru in Dahschur." Annales du service des antiquités de l'Égypte 52 (1954): 609, argues that the mortuary temple at the Bent Pyramid predates that at Meidum.

${ }^{106}$ Ahmed Fakhry, The Monuments of Sneferu at Dashur (Cairo: General Organization for Government Printing Offices, 1959-1961), 26; and Ahmed Fakhry, "The excavation of Snefru's Monuments at Dashur," 563-594; Ricke, "Baugeschichtlicher vorbericht über die kultanlagen der südlichen pyramide des Snofru in Dahschur," 606-07.

${ }^{107}$ Colin Reader, "On Pyramid Causeways," JEA 90 (2004): 63-71.
} 
the eastern corner of the north side, and then bends to head largely east, but slightly north. ${ }^{108}$ Its course was likely influenced by the topography of the area. ${ }^{109}$ This causeway leads to a "Valley Temple," though this Valley Temple is different from it successors, for after the Valley Temple the causeway continued for 148 meters more, ending in an apparent "harbor basin." 110 The Bent Pyramid also had a small chapel on its northern side that contained an altar. ${ }^{111}$

The Red Pyramid is more like its successors than Snefru's other pyramids. It too has a northern entrance. ${ }^{112}$ The passage from this entrance leads to two chambers that run north-south, but these lead to the burial chamber, which is on an east-west axis for the first time. ${ }^{113}$ Snefru constructed a temple on the eastern side which is larger than those at his other pyramids, though still small compared with its successors at Giza or Abu Rowash. ${ }^{114}$ There are early excavation reports of the remains of a causeway (which may have only been used for transporting materials) ${ }^{115}$ and a valley temple to the east of the pyramid. ${ }^{116}$ There are also the remains of holes for holding pots, though the reports do not provide sufficient detail to compare to similar finds elsewhere.

[page 74]

Of Snefru's four pyramids, Seila and the Bent Pyramid are the only ones to exhibit evidence for ritual activity on the north side, though both have larger structures on the east and contain

\footnotetext{
${ }^{108}$ Fakhry, The Monuments of Sneferu at Dashur, 36.

${ }^{109}$ Nicole Alexanian, Wiebke Bebermeier, Dirk Blaschta, Arne Ramisch, Brigitta Schutt, and Stephan Johannes Seidlmayer, "The Necropolis of Dahshur Seventh Excavation Report Autumn 2009 and Spring 2010," German Archaeological Institute: 11-15.

${ }^{110}$ Nicole Alexanian, Felix Arnold, Dirk Blaschta, Josuah Pinke, and Stephan Johannes Seidlmayer, "The Necropolis of Dahshur Ninth Excavation Report Autumn 2011 and Spring 2012," German Archaeological Institute/Free University of Berlin, 5-6.

${ }^{111}$ Miroslav Verner, The Pyramids: The Mystery, Culture, and Science of Egypt's Great Monuments, Steven Rendall, trans. (New York: Grove Press, 2001), 178. Edwards, "The Pyramid of Seila and its Place in the Succession of Snofru's Pyramids," 90. Fakhry, The Monuments of Sneferu at Dashur, 70.

112 Fakhry, The Pyramids, 97.

${ }^{113}$ Nils Billing, "Monumentalizing the Beyond: Reading the Pyramid before and after the Pyramid Texts," SAK 40 (2011): 56. On the change, see Roth, "Social Change in the Fourth Dynasty," 45.

${ }^{114}$ Rainer Stadelmann, Nicole Alexanian, Herbert Ernst, Günter Heindl, and Dietrich Raue, "Pyramiden und Nekropole des Snofru in Dahschur. Dritter Vorbericht über die Grabungen des Deutschen Archäologischen Instituts in Dahschur," MDAIK 49 (1993): 263-65; Rainer Stadelmann, "Die Pyramiden des Snofru in Dahschur. Zweiter Bericht über die Ausgragungen an der nördlichen Stein pyramide," MDAIK 39 (1983): 228-29; Ranier Stadelmann and H Sourouzian, "Die Pyramiden des Snofru in Dahschur," MDAIK 38 (1982): 379-93; Edwards, "The Pyramid of Seila and its Place in the Succession of Snofu's Pyramids," 90

115 On issues regarding the causeway, see Butler, Egyptian Pyramid Geometry, 163; Isler, Stick, Stones, and Shadows, 214-15; and Verner, The Pyramids: The Mystery, Culture, and Science of Egypt's Great Monuments, 187. ${ }^{116}$ Lehner, Complete Pyramids, 105; Arnold, Red Pyramid, in The Monuments of Egypt: An A-Z Companion to Ancient Egyptian Architecture, 199.
} 
evidence for ritual activity there as well (at Seila in the form of the holes for pots, the presence of stelae where offerings could have been centered is indicated, ${ }^{117}$ and in the fragments of what seems to be an altar). The Seila Pyramid had stelae on the eastern side, as did the Bent and Meidum Pyramids. The Meidum stelae were both uninscribed, the Bent stelae were all inscribed, and the Seila Pyramid had one inscribed stela and one that was perhaps uninscribed. It seems to be identical to the Meidum Pyramid in having a causeway on the east with no structure attached to the lower part of that causeway. At the same time, as will be seen in the chart below, it has many shared affinities with the Bent Pyramid. These cultic elements are summarized in the following table:

$\underline{\text { Table } 1}$

\begin{tabular}{|l|l|l|l|l|l|l|}
\hline Pyramid & $\begin{array}{l}\text { Burial Chamber } \\
\text { Orientation }\end{array}$ & Side of Entrance & Adjacent Structure & Cause-way & Valley Temple & Altars \\
\hline Seila & None (uncertain) & $\begin{array}{l}\text { None } \\
\text { (uncertain) }\end{array}$ & $\begin{array}{l}\text { Porch on East and } \\
\text { North }\end{array}$ & East & No & $\begin{array}{l}\text { Two on north, } \\
\text { perhaps one on } \\
\text { east }\end{array}$ \\
\hline Meidum & North-South & North & East temple & East & No & One on east \\
\hline Bent & North-South & North and West & East and North & North-East, & Yes & One on east, one \\
on north
\end{tabular}

The Seila Pyramid sits at the junction of pyramid cultic activity that focused on the north of the pyramid and an emerging cultic focus on the east. Future publications will explore: the purpose of the Seila Pyramid, which was clearly not intended to house the king's dead body; the timing of when the Seila Pyramid was built as compared to Snefru's other pyramids; questions about what [page 75] kinds of activities would have happened in Seila's cultic structures; the relationship between the Seila Pyramid and Snefru's other pyramids, asking what can looking at all of them together tell us about the development of the pyramid complex; and analyzing what the Seila Pyramid's relationship is to the minor step pyramids and what that relationship can tell

\footnotetext{
117 Stadelmann, "Snofro - Builder and Unique Creator of Pyramids of Seila and Meidum," 38; Andrzej Ćwiek, "Date and Function of the So-Called Minor Step Pyramids," 52.
} 
us about the development of the concept of pyramids. Clearly there is more work to be done in exploring and analyzing the Seila Pyramid. Yet it is already apparent that the Seila Pyramid was a site of innovation in architecture, in orientation, in titular inscription, in ritual activity, and in use of spatial geography. We look forward to creating future publications that will further all of these topics and thus will allow us to better understand the beginning of the pyramid age. 